\title{
Locally advanced renal cell carcinoma: cause of upper gastrointestinal bleeding
}

\author{
Sarthak Soin, ${ }^{1}$ Eugene Verkhovsky ${ }^{2}$
}

'Internal Medicine, Presence Saint Joseph Hospital Chicago, Chicago, Illinois, USA

${ }^{2}$ Gastroenterology and Hepatology, Banner University Medical Center Tuscon, Tucson, Arizona, USA

\section{Correspondence to}

Dr Sarthak Soin

sarthaksoin@gmail.com

Accepted 1 April 2019

\section{DESCRIPTION}

Renal cell carcinoma (RCC) most commonly develops in the sixth and seventh decade of life and has a male preponderance 2:1. ${ }^{12}$ Primary RCC presenting as upper or lower gastrointestinal bleeding as a result of direct extension is uncommon with only few case reports being described in the literature. ${ }^{13-6}$ Metastatic spread involves haematogenous, lymphatic, transcelomic and direct invasion. Direct invasion of the second part of the duodenum is likely due to its anatomical relationship with the right kidney anteriorly. Management of the

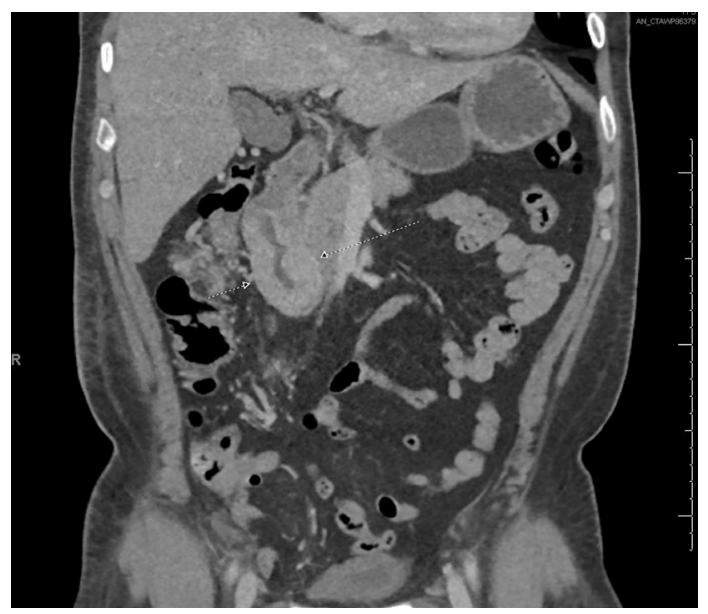

Figure $1 \mathrm{CT}$ abdomen and pelvis arrows showing the right renal mass involving the second part of the duodenum.

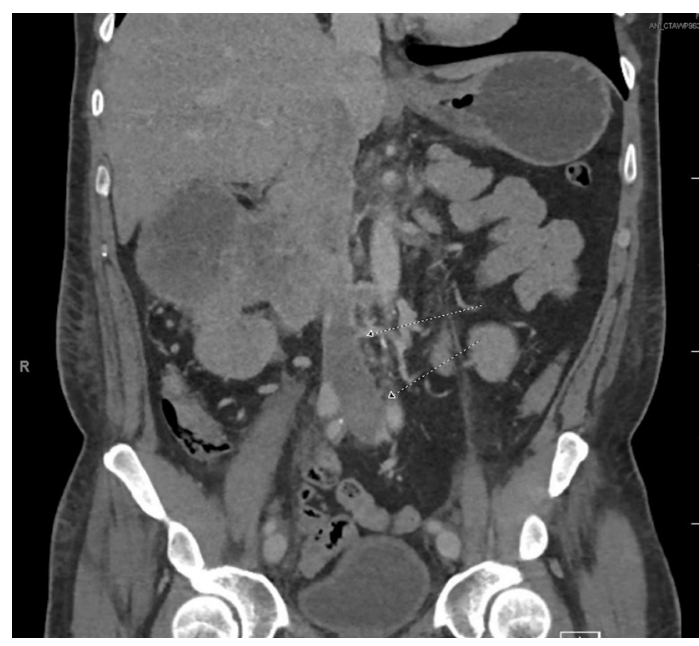

Figure 2 CT abdomen and pelvis arrows showing the right renal mass involving the inferior vena cava extending into the left common iliac vein.

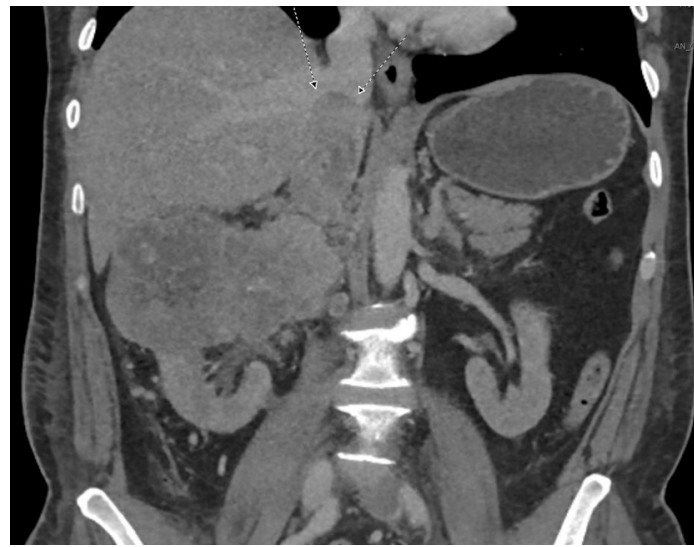

Figure $3 \mathrm{CT}$ abdomen and pelvis arrows showing the right renal mass involving the inferior vena cava extending into the hepatic venous confluence.

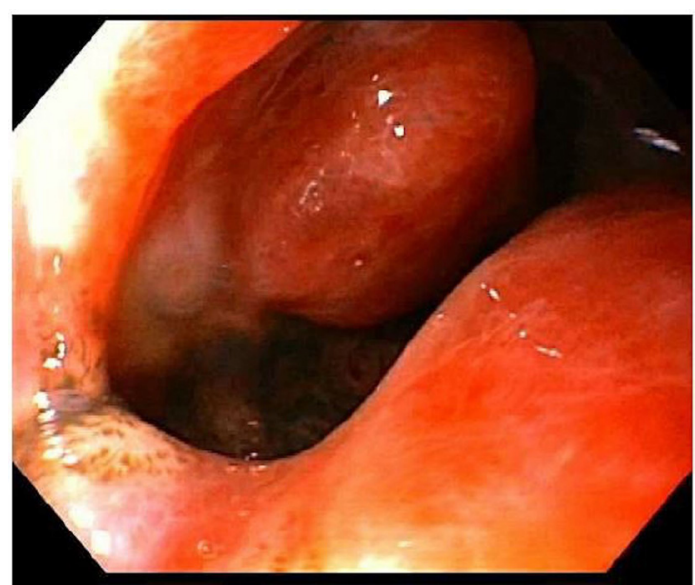

Figure 4 Oesophagogastroduodenoscopy showing bleeding masses arising from the second part of the duodenum.

locally advanced RCC involving the second part of duodenum can involve performing pancreaticoduodenectomy along with cytoreductive nephrectomy and early use of checkpoint inhibitor immunotherapeutic agents like sunitinib.

A 53-year old man presented to the emergency department with complaints of melena and fatigue for 2 weeks. It was associated with persistent aching of the right-sided abdominal pain, non-radiating and partially relieved with non-steroidal anti-inflammatory drugs. Medical history is significant for 40 pack-year smoking and alcohol abuse.

On admission, his vitals are as follows: blood pressure $100 / 60 \mathrm{~mm} \mathrm{Hg}$, heart rate $126 / \mathrm{min}$, saturating $92 \%$ on room air and temperature $36^{\circ} \mathrm{C}$. 
Physical examination was significant for conjunctival pallor, mild tenderness over the right upper quadrant and pitting lower extremity oedema. No guarding or rigidity, palpable abdominal mass was present on examination. The rest of the physical examination was unremarkable.

Blood workup showed haemoglobin $2.3 \mathrm{~g} / \mathrm{dL}$, blood urea nitrogen $58 \mathrm{mg} / \mathrm{dL}$ and white cell count $74 \times 10^{9} / \mathrm{L}$. CT abdomen and pelvis with intravenous contrast showed right kidney mass measuring $14.4 \times 9.6 \times 9.8 \mathrm{~cm}$, tumour infiltrating the second part of the duodenum and right renal vein extending into the inferior vena cava, coursing into the hepatic venous confluence cranially and left common iliac vein caudally (figures 1-3). He was transfused five units of packed red blood cells ( $p R B C$ ) and subsequently underwent oesophagogastroduodenoscopy which showed bleeding masses arising from the second part of the duodenum (figure 4). Interventional radiology performed

\section{Learning points}

- The presence of renal cell carcinoma (RCC) classic triad of flank pain, haematuria and palpable abdominal pain suggests an advanced disease.

- Increased age, smoking, obesity and long-term dialysis are important risk factors for the development of RCC.

- Lungs, lymph nodes, liver, pancreas, bone, brain and contralateral kidney are the most common sites of metastasis. microfoil and surgifoam embolisation of the branches of the gastroduodenal artery supplying blood flow to the duodenum which had tumorous invasion to achieve haemostasis. Urology and oncology were consulted for palliative cytoreductive surgery followed by chemo/immunotherapy.

Contributors SS and EV contributed equally in writing and reviewing of the manuscript.

Funding The authors have not declared a specific grant for this research from any funding agency in the public, commercial or not-for-profit sectors.

Competing interests None declared.

Patient consent for publication Obtained.

Provenance and peer review Not commissioned; externally peer reviewed.

\section{REFERENCES}

1 Schlussel AT, Fowler AB, Chinn HK, et al. Management of locally advanced renal cell carcinoma with invasion of the duodenum. Case Rep Surg 2013;2013:1-4.

2 Siegel R, Naishadham D, Jemal A. Cancer statistics, 2012. CA Cancer J Clin 2012;62:10-29.

3 Ramírez Fabián M, Vicente Aldea MT, Ambroj Navarro C, et al. [Rectal hemorrhage as a first sign of renal cell adenocarcinoma]. Actas Urol Esp 1998;22:599-601.

4 Perez VM, Huang GJ, Musselman PW, et al. Lower gastrointestinal bleeding as the initial presenting symptom of renal cell carcinoma. Am J Gastroenterol 1998;93:2293-4.

5 Mohamed MO, Al-Rubaye S, Reilly IW, et al. Renal cell carcinoma presenting as an upper gastrointestinal bleeding. BMJ Case Rep 2015;2015:bcr2015211553.

6 Street R, Brady J, Slobodav G. Renal cell carcinoma presenting with Melena from direct invasion into the duodenum: a case report and a review of literature. J Okla State Med Assoc 2013;106:477-9.

Copyright 2019 BMJ Publishing Group. All rights reserved. For permission to reuse any of this content visit https://www.bmi.com/company/products-services/rights-and-licensing/permissions/

BMJ Case Report Fellows may re-use this article for personal use and teaching without any further permission.

Become a Fellow of BMJ Case Reports today and you can:

- Submit as many cases as you like

- Enjoy fast sympathetic peer review and rapid publication of accepted articles

- Access all the published articles

- Re-use any of the published material for personal use and teaching without further permission

For information on Institutional Fellowships contact consortiasales@bmjgroup.com

Visit casereports.bmj.com for more articles like this and to become a Fellow 